\title{
TOP MANAGEMENT COMMITMENT AND SALES FORCE PERFORMANCE OF BEVERAGE MANUFACTURING COMPANIES IN NIGERIA
}

\author{
Ini Smart Udoh ${ }^{1}$, Andrew Amuamuziam Okwudu ${ }^{2}$ and Dr. Uduak E. Joseph ${ }^{3}$ \\ Department of Marketing, University of Uyo, Uyo.
}

\begin{abstract}
This study was designed to examine the influence of top management commitment on salesforce performance in selected beverage manufacturing firms in Nigeria. The study population was 151 and made up of all persons that are involved in sales of both alcoholic and non-alcoholic beverages manufactured in Nigeria. The major instrument for data collection was the questionnaire. The proxies for top management commitment were leadership, management involvement, management support and resource allocation. The instrument was administered to every member of the population out of which 142 copies of the questionnaire were completed and returned in useable form. Data collected were analyzed using percentage analysis and hypotheses formulated were tested using the multiple regression analysis. Findings from the study revealed that there is significant relationship between the top management variables (i.e. leadership, management involvement, management support and resource allocation) and salesforce performance. Based on the findings, it was concluded that top management commitment influences salesforce performance in the beverage manufacturing companies in Nigeria. Consequently, it is recommended, among other things, that top management should show leadership by driving improvement that will enhance sales through the performance of the sales team. Also, they should allow team members' input into decision making on issues concerning sales.
\end{abstract}

KEYWORDS: leadership, involvement, support, resource allocation, management, salesforce, performance.

\section{Introduction}

Sales is seen as the medium through which prosperity comes into firms, because a firm that cannot sell its goods or services cannot bring in revenue and subsequently profit. Sales, in most organization, are handled by salespeople. However, the sales force is always plagued with challenges, what seems to be the most important challenge faced by them is designing strategies to improve their sales performance.

Sales force functions and activities does not only constitute the largest portion of a firm's marketing budget but also a primary source of revenue and a key to organizational success (MacKenzie, 2019). This leads to organizations having interest in identifying the variables that influence sales performance (Johnston and Marshall, 2003). Past researches indicates that one such variable is top management commitment (Vinchur and Denise, 2019). This is because top management commitment implies the direct participation, dedication, steadfastness and devotedness to getting things done by the highest level of management in all specific and critically important aspects or programs and strategies of an organization.

ECRTD-UK https://www.eajournals.org/

ULR: https://doi.org/10.37745/ijbmr.2013 
Vol.10, No.1, pp.1-12, 2022

Print ISSN: 2052-6393(Print),

Online ISSN: 2052-6407(Online)

Top management forms the highest decision making body within the organization. They are made up of the highest officials or executives in the organization responsible for achieving goals through and with other members (Wheelen and Hunger, 2006). Top management commitment anchors on leadership, resources allocation, management involvement and management support (Stevens and Stevens, 2015). Hence, they must have the skills to manage the strategic planning process effectively (Wheelen and Hunger, 2006). They occupy a decisive position on the success or failure of the organization.

The task of top management is multidimensional and oriented towards the achievement of overall organizational prosperity developed from the mission, goals, strategies and business processes of the organization. It is therefore anticipated that sales personnel and sales managers of beverage manufacturing companies will benefit from the outcome of this study. Their understanding of areas where commitment is required of them, as well as its contributions to enhancing sales performance will be further refined. This is likely to bring about improvement on intervention policies and programs that will address the issue of poor sales performance.

\section{Statement of the Problem}

Top management commitment and sales performance in firms is rapidly gaining interest, particularly because top management decides on the appropriate sales strategies to be used in line with firms' mission and vision. Past researches that sought to establish a relationship between top management commitment and sales performance presented mixed findings. While some studies found that top management commitment aids sales performance, others either found the relationship to be negative or non-significant. Still, some studies showed inverse relationships which were explained by mediating or moderating variables. Moreover, the relationship between top management commitment and sales performance was found to be weak and mixed in previous meta-analyses conducted in the marketing literature with samples consisting of a variety of sales persons. Finally, Most of the studies were not targeted at Nigeria or even the manufacturing companies. Therefore this study seeks to know what the result would be if similar variables are studied in the Nigerian manufacturing industry given that they operate in a different environment.

\section{Objectives of the Study}

The main aim of this study is to examine the relationship between top management commitment on salesforce performance in beverage Manufacturing companies in Nigeria. Specifically the objective for this study is to:

i. Examine the collective relationship between management leadership, involvement, support, and resources allocation and salesforce performance in selected beverage manufacturing companies in Nigeria.

\section{Research Question}

The above objective led to the research question:

i. To what extent does management leadership, involvement, support, and resources allocation collectively relate with salesforce performance in selected beverage manufacturing companies in Nigeria?

ECRTD-UK https://www.eajournals.org/

ULR: https://doi.org/10.37745/ijbmr.2013 


\section{Research Hypotheses}

The study's objective resulted in the hypothesis which states that:

i. There is no collective significant relationship between management leadership, involvement, support, and resources allocation and salesforce performance in selected beverage manufacturing companies in Nigeria.

\section{REVIEW OF RELATED LITERATURE}

\section{a. Conceptual Framework}

\section{Top Management Commitment}

Commitment comes from the Latin word "Committere" which means combining, uniting, believing and doing it (Snyder, 1994). Explicitly, Chatterjez (2006) states that commitment is an agreement on the part of an organizational participant to the missions and objectives of an organization including explicit and implicit willingness to work to their achievement. Furthermore Durkin (1999) defines commitment as a strong feeling of a person toward the goals and values of an organization, in terms of their role toward achieving the goals and values. In the context of this study, Noe, Bulliard, and Tyrone (2000), defines top management commitment as the degree to which a senior employee identifies with the organizational goals and willing to put in effort to achieve them. The same opinion is expressed by Robbins (2007) that the top management commitment is the degree to which a senior employee identifies with a particular organizational goal and wishes to exert energy and effort, both mentally and physically, in order to achieve such goals. Summing it up, top management commitment can be defined as a definite belief in, and acceptance of, the value and goals of the organization by highest level executives of the organization and a willingness to exert a high level of effort in achieving same on behalf of the organization.

Top management commitment is a critical and crucial requirement for institutional success in any area of business operation (Evans and Dean, 2003; Kanji, 2002). According to them, top management commitment provides a critical point for the vivacities, hopes and aspirations of people in organizations. They are responsible for controlling and overseeing the entire organization. They develop goals, strategic plans, company policies, and make decisions on the direction of the business and also plays a significant role in mobilizing outside resources. Vinchur and Denise (2019) assert that firms with committed executives tend to be more competitive in their overall service offerings, have loyal customers, reliable and flexible in their deliveries, and receive fewer complaints from customers. They recommended that given the inherent benefits of having committed executives in the organization, employers should endeavor to motivate their employees to the right level of commitment.

Different dimension and constructs of top management commitment have been put out by different authors. For instance, Juran (1988) referred to commitment as leadership, resources allocation, and support. On his part, Biggar (2010) found understanding and support as the constructs for management commitment. Crosby (2019) stated that participation, and having the right attitude reflect the commitment of management. Goetsch, David and Fally (2019) emphasised involvement, and resources allocation. Similarly, Ahire, Sanley and Matthew (1998) underscored involvement, support and resources allocation. On the same issue, Harris, Maddison and McCaffer (2001) were more concerned on leadership whereas Taylor, Fred and Wright (2003) looked at involvement, support and resource allocation. From the above and for

ECRTD-UK https://www.eajournals.org/

ULR: https://doi.org/10.37745/ijbmr.2013 
Vol.10, No.1, pp.1-12, 2022

Print ISSN: 2052-6393(Print),

Online ISSN: 2052-6407(Online)

the purpose of this study, management commitment was summarized into four constructs. These are management support, leadership, management involvement and resources allocation.

\section{a. Leadership}

As stated by Zakuan, Luna and David (2012), managers must institute leadership to usher in the transformation process. Parameshwar, Srikantia and Case (2000) discussed two types of leadership: transformational leadership and transactional leadership. Transformational leadership is leadership that is based on an ideologically anchored vision while transactional leadership is based on reward control mechanisms and emphasizes on clarification of followers roles and goals and the way the desired outcome will follow after achievement of the set goals. Champions of innovation tend to exhibit transformational leadership behaviour; they try to initiate influence through calculated tactics in their work environment.

\section{b. Management Involvement}

Management involvement in management operations can be direct (personally involved) or indirect (through delegation). Also, management involvement can either be active or passive. The level of management involvement in sales is indicative of the level of its commitment to achievement of higher sales performance (Yoshida, 2017). Arshida and Agil (2012) point out top management involvement is an essential element for ensuring successful business outcome, top managers must be on the fore front of the process of driving sales growth. According to Omware (2012), this process is associated with development of new organizational policy, new procedures and new marketing tools that must be applied. Sales performance is often associated with uncertainty because of difficult competitive and other environmental landscape. As such, it must be carefully initiated through consistent management involvement and strategy development. This was consistent with Samir (2003) who opine that top management must develop clear mission and goals and identify market values and communicate them to all employees. They must put in place proper sales plan, and a good management structure to ensure successful implementation. This is consistent with the result of empirical study on management involvement in Palestinian organizations conducted by Baidoun (2003). He stated that top management involvement is demonstrated by development of clear organization mission, clear policy and values, setting of realistic goals and proper planning which are necessary factors to business success.

\section{c. Management Support}

Top Management play a critical role in key business decisions. Consequently, the success of any critical decision made in an organization depends largely on top management support and commitment (Zakuan et al., 2012). Market share growth is of great importance to every organization involved in production and no management can afford to let natural occurrence take its course when it comes to market share drive. The top management must play a leading role by making available the necessary resources, establishing very clear policy that is well communicated to all stakeholders, establishing a management structure and managing the entire process through close monitoring and evaluation.

\section{d. Resources allocation}

To drive sales performance and growth, sufficient resources must be provided (Timo, 2018). Basically, there are five types of resources: human, material, machineries/technology financial resources and time (Dangara, 2016). The management of an organization plays the role of

ECRTD-UK https://www.eajournals.org/

ULR: https://doi.org/10.37745/ijbmr.2013 
Vol.10, No.1, pp.1-12, 2022

Print ISSN: 2052-6393(Print), Online ISSN: 2052-6407(Online)

distributing resources for various needs. A management is seen as committed to sales performance when adequate allocation of sufficient resources is made for the purpose (Parameshwar et. al., 2000).

Deciding how to allocate marketing resources is particularly difficult because decisions need to be made at many levels (Gupta and Mirjana, 2000). According to Rybacka (2018), resource allocation to sales is important because it gives a clear picture of the level of commitment of top management to sales performance in the organization. It also helps to schedule ahead and have an insight into the team's progress, including allocating the right amount of time to everyone on the team. Resource allocation makes for proper planning and implementation of sales strategies to aid achieve pre-set goals.

\section{Sales Performance}

Sales in business terms are the actual sales in money values, a company receives after necessary collections are made from different sales channels of the original total production that was put on the market McCathy, Pandi and Lande (1994). It is the quantity of goods sold in number or amount of units during the normal operating times of a company (Moghareh, Ghazaleh and Haghighi, 2009). Also, it can be seen as the total amount of aspects comprising gross sales, credit memos, income, delayed billings and delayed shipments. It is sales that stimulate production in a company and consequently profits which are affected by various factors some of which are controllable like management commitment and others are uncontrollable like competition and general price changes.

Sales performance is an integrated frame work that enables organizations to plan and model sales strategies and ensure timely execution of sales initiatives while ensuring both frontline sales people and decisions-markers have visibility into performance (Michael, 2006). Sales performance also refers to the total amount of firm's output sold to the market especially on monthly or annual basis (Amanda, 2002). It can be seen as the measurement of sales activity against the goals outlined in your sales plan (Caborne, 2018). The sole economic goal of companies is to have as much goods sold on the market. This facilitates the rate of goods turnover and consequently revenue and increased production.

Designing or adopting sales strategies is critical to enhancement of sales performance. According to Frederick (2016), the designing or adopting appropriate sales strategies is the work of top management. As a result, their commitment is key to the success of such strategies. In his opinion, Adam (2014) says that the sales strategies must be developed based on the company's unique situation in their market, their customers, competitive pressures , reporting requirements, participating partners and the skill level of their current sales people (Stein, 2006).

According to Hardesty (2006), the crafting of sales strategy and programs is serious business and demands the commitment of top management. This is because sales strategy and programs encompass a variety of necessary components, like company policies, sales paperwork, customer relationship management, sales force automation orientation, sales processes and sales skill training. Most of these components are strategic components that demand action from top management. In his opinion, Hamilton (2017) said sales performance can only be enhanced when these strategic components are taken care of appropriately by organisation's

ECRTD-UK https://www.eajournals.org/

ULR: https://doi.org/10.37745/ijbmr.2013 
Vol.10, No.1, pp.1-12, 2022

Print ISSN: 2052-6393(Print),

Online ISSN: 2052-6407(Online)

top executives as sales strategies and programs must be properly aligned with firm's objectives. Besides aligning sales strategies with organizational objectives, top management must be committed to the achievement of the goals set by the organization (Simpson and Ederson, 2018). Hamilton (2017) established that the proxies of management involvement in sales, management support of sales, and resources allocation to sales in that order, impacted on customer patronage. They author recommends that top management must focus on improving these proxies to enhance customer patronage.

\section{Theoretical Framework}

This study is founded on the investment theory of commitment by Caryl Rusbult. This theory which was propounded in 1983 is rooted in interdependence theory, proposed by John Thibaut and Harold Kelley in the late 1950s. More specifically, Rusbult (1983) uses the interdependence concepts of dependence, comparison level, and comparison level for alternatives as the basis for the investment theory of commitment. The investment theory of commitment holds that commitment is the subjective experience of dependence and is a function of three independent variables: satisfaction level, quality of alternatives, and investment size.

Satisfaction level refers to the positive versus negative effect experienced in an employee's relationship with the organization. Putting is simply, Satisfaction level refers to the relative positivity of outcomes obtained in interactions with the organization. Outcomes are assessed with respect to a person's comparison level for similar outcomes within a given sphere of influence. Satisfaction is influenced by the extent to which the organization fulfills the employee's most important needs.

Quality of alternatives relates principally to available alternatives. Broadly speaking, quality of alternatives refers to the satisfaction envisioned as attainable beyond the current position. That is quality of alternatives refers to the perceived desirability of the best available alternative to a relationship. Quality of alternatives is based on the extent to which the individual's most important needs could effectively be fulfilled "outside" of the current organization -in a specific alternative involvement, by the broader field of eligible.

Investment size refers to the magnitude and importance of the resources (both tangible and intangible) that one may have put in a job - resources that would decline in value or be lost totally if the relationship between the employee and the organization were to end (Teger and Tropper, 2013). As the relationship develops, stakeholders in the organization invest many resources directly into the organization in the hope that doing so will improve it. Moreover, some investments are indirect, and come into existence when originally extraneous resources become attached to the investment relationship. Invested resources presumably enhance commitment because the act of investment increases the resultant costs of ending a relationship with the organization, serving as a powerful psychological inducement to persist.

The Investment Model further suggests that feelings of commitment emerge as a consequence of increasing dependence. Commitment level is defined as intent to persist in adding value to the organization by constantly engaging in acts that will lead toward achieving the goals and values of the organization. Collectively, satisfaction level, quality of alternatives, and investment size are posited to influence commitment level. A given job reality may be driven

ECRTD-UK https://www.eajournals.org/

ULR: https://doi.org/10.37745/ijbmr.2013 
Vol.10, No.1, pp.1-12, 2022

Print ISSN: 2052-6393(Print),

Online ISSN: 2052-6407(Online)

by one or more of these factors and these factors have been found to work together in an additive fashion to influence commitment. Commitment level itself has been found to be associated with a number of maintenance behaviors, such as willingness to sacrifice for one's ambition and forgiveness of betrayal by a team member. Commitment level has also been found to mediate the effects of satisfaction level, quality of alternatives, and investment size on the enactment of such behaviors.

\section{METHODOLOGY}

The study used the survey research design approach and the population of this study consisted of all persons that are involved in sales of alcoholic and non-alcoholic beverages from selected companies. These persons were sales representatives (SR), depot managers (DM), district sales managers (DSM), regional trade marketing managers (RTMM), van salesmen (VSM) and regional business managers (RBM). Altogether 151 persons made up the sample size for the study given the small population size. Further, the census method of statistical enumeration was employed in administering copies of the questionnaire to everyone that made up the population.

The instrument for this research was made by the researcher after a thorough review of existing literature on the subject matter. The instrument was divided into two parts. The first part sought for demographic information while the second part collected data on top management variables and sales performance. The Cronbach (Alpha) model was employed to test the reliability of the instrument. A Cronbach alpha reliability coefficient of 0.71 was achieved. This level of Cronbach's coefficient was considered enough to justify the use of the instrument.

Data collected for this study were analysed using descriptive statistics and hypotheses formulated were tested using simple linear regression analysis. All hypotheses were tested at $5 \%$ level of significance.

\section{Data Presentation and Analysis}

The total copies of questionnaire that were accurately filled and returned were 142 copies out of the 151 that were distributed. This constitutes $94 \%$ of the total copies of questionnaire that were found relevant for the study, 9 copies of questionnaire were returned incompletely filled, hence were discarded. A breakdown of respondents feedback are as follows:

\section{Table 1: Respondents' Profile}

\begin{tabular}{llll}
\hline S/N & $\begin{array}{l}\text { Sample } \\
\text { Characteristics }\end{array}$ & $\begin{array}{l}\text { Number } \\
\text { Respondents }\end{array}$ & Respondents (\%) \\
\hline $\mathbf{1}$ & Sex & & \\
& Male & 109 & 76.8 \\
$\mathbf{2}$ & Female & 33 & 23.2 \\
& $\begin{array}{l}\text { Length of Time Spent } \\
\text { on Current Job }\end{array}$ & & \\
& 1 - 5 years & 76 & 53.5 \\
& 6- 10 years & 41 & 28.9 \\
& Above 10 years & 25 & 17.6 \\
$\mathbf{3}$ & Education & 69 & 48.6 \\
& ND/NCE & 59 & 41.5 \\
& HND/B.Sc. & 14 & 9.9 \\
& M.Sc./MBA & 0 & 0.0 \\
\hline
\end{tabular}

Source: Field survey, (2021).

ECRTD-UK https://www.eajournals.org/

ULR: https://doi.org/10.37745/ijbmr.2013 
Vol.10, No.1, pp.1-12, 2022

Print ISSN: 2052-6393(Print),

From the results of analysis on Table 1, male and female respondents constituted $76.8 \%$ and $23.2 \%$ respectively. In terms of length of time spent on the job, $53.5 \%$ of the respondents said they had spent between 1 and 5 years on the job, 28.9\% had spent between 6 and 10 years, while $17.6 \%$ said that they had spent above 10 years on the job. Furthermore, of the 142 respondents, $48.6 \%$ were holders of ND/NCE. Holders of HND/BSc were $41.5 \%$ while holders of $\mathrm{MSc} / \mathrm{MBA}$ were $9.9 \%$. None of the respondents had a Ph.D.

\section{Data Presentation and Interpretation}

Ho1: There is no collective significant relationship between management leadership, involvement, support, and resources allocation and salesforce performance in selected beverage manufacturing companies in Nigeria. in Nigeria.

Table 2: Results of Multiple Regression analysis between top management commitment and sales performance

\begin{tabular}{|c|c|c|c|c|c|}
\hline & $\mathbf{B}_{1}$ & SE & $\mathbf{B}_{2}$ & t-value & $\begin{array}{l}\text { Significant } \\
(2 \text { tailed })\end{array}$ \\
\hline Constant & .846 & .674 & - & 1.255 & .212 \\
\hline Leadership & .809 & .104 & .713 & 7.756 & .000 \\
\hline Involvement & -.638 & .116 & -.614 & -5.512 & .000 \\
\hline Support & .946 & .065 & .877 & 14.577 & .000 \\
\hline Resource allocation & .009 & .061 & .009 & .154 & .878 \\
\hline $\begin{array}{l}\text { Dependent Variable: } \quad \text { Salesforce } \\
\text { performance }\end{array}$ & & & & & \\
\hline $\mathrm{R}=$ & 0.900 & & & & \\
\hline $\mathrm{R}^{2}=$ & 0.810 & & & & \\
\hline Adjusted R-Square = & 0.805 & & & & \\
\hline Std. Error of estimate $=$ & 0.83289 & & & & \\
\hline F-statistics $($ ANOVA $)=$ & 146.390 & & & & \\
\hline Significance P-Value (ANOVA) $=$ & $0.000^{\mathrm{b}}$ & & & & \\
\hline
\end{tabular}

Source: Researcher's Computation.

In a bid to empirically establish whether the dimensions of top management commitment: management leadership, involvement, support, and resources allocation significantly relates with salesforce performance, the t-test statistics was used to test the significance of the $\beta$ parameter of top management commitment dimensions to salesforce performance. Where:

Salesforce performance $(\mathrm{Sp})=\mathrm{a}_{0}+\beta_{1} \mathrm{Ml}+\beta_{2} \mathrm{Mi}+\beta_{3} \mathrm{Ms}+\beta_{4} \mathrm{Ra}+\ldots \mathrm{e} \quad$ Equation 1

On Table 2, the estimated regression weights, standard errors and $\mathrm{p}$-values for all the predictors are given, results also indicates; $\mathrm{a}_{0}=0.846$, the intercept $/ \mathrm{t} /$ - Salesforce performance $=1.255$ with a p-value of 0.212 .

From the results, resource allocation was not a significant predictor of salesforce performance, based on its $p$-value $(\beta=0.009, p=.878)$. However, leadership $(\beta=0.809$, $p$-value $<0.000)$; involvement $(\beta=-.638, \mathrm{p}<0.00)$; and support $(\beta=0.946, \mathrm{p}<0.00)$ were all significant predictors of salesforce performance. The variable involvement had a negative relationship with salesforce performance. Based on this result, it can empirically be established that the intercept $\mathrm{a}_{0}$ is significant and that top management dimensions such as management leadership, involvement, and resources allocation in the regression equation significantly relates to salesforce performance.

ECRTD-UK https://www.eajournals.org/

ULR: https://doi.org/10.37745/ijbmr.2013 
Vol.10, No.1, pp.1-12, 2022

Print ISSN: 2052-6393(Print),

The coefficient translates to every one unit change in Management Leadership at the company, will lead to 0.809 positive change in sales force performance. Also, every one unit change in management involvement will lead to a -0.638 negative change in salesforce performance. Further, every one unit change in management support will lead to 0.946 positive change in sales performance. Last, every one unit change in resource allocation, will lead to a 0.009 positive change in salesforce performance. The resulting model will be:

Salesforce performance $(\mathrm{Sp})=0.846+0.809 \mathrm{Ml}+(-0.638 \mathrm{Mi})+0.946 \mathrm{Ms}+0.009 \mathrm{Ra}$

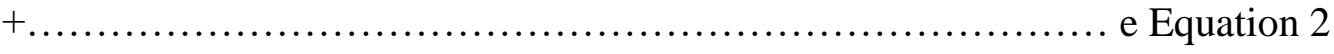

$\mathrm{Sp}=0.846+0.809 \mathrm{Ml}-0.638 \mathrm{Mi}+0.946 \mathrm{Ms}+0.009 \mathrm{Ra} \quad+\ldots \ldots . . \mathrm{e} \quad$ Equation 3

The values of F-statistics $=146.390$ and Significance statistics $p$-value $=0.000$ in the model indicates that the resulting regression model (equation 3) is useful and that management leadership, involvement and support are significant predictors of salesforce performance.

\section{DISCUSSION OF FINDINGS}

Generally, the results of the study reveals a combined positive significant relationship between the predictor variables; leadership, management involvement, management support, resource allocation and the criterion variable; sales performance in beverage companies in Nigeria. This implies that top management commitment have a significant relationship with sales performance in $n$ beverage manufacturing companies in Nigeria. This result is in agreement with the findings of Hadesty (2006); Adam (2014); and Fredericks (2016) who in their studies at different geographical locations found that top management elements are positively and significantly related to sales performance in organisations. Taking management involvement, for instance, Fredericks (2016) states that management involvement contributes significantly to sales performance in that top management involvement is an essential element for ensuring successful business outcome. He further opine that when top managers are on the fore front of the process of driving sales growth, better sales performance 0is guaranteed to greater extent. Also, Adam (2014) opine that management support is a major determinant of sales performance in organisation and suggest that the more support the sales team enjoy from top management the more they are likely to do well. Furthermore, Simpson and Ederson (2018) who, similarly, found a significant correlation between top management commitment and sales performance in a survey of manufacturing firms in the Swedish city of Stockholm, explained that if organisations intend to enjoy higher sales performance, then top executive of the organisation must be committed to improving sales through their involvement in what is being done to drive sales, their support to the sales team, show of leadership and adequate allocation of needed resources.

\section{CONCLUSION}

Based on the findings of this study, it is concluded that there is significant relationship between top management commitment and sales performance in beverage manufacturing companies in Nigeria.

ECRTD-UK https://www.eajournals.org/

ULR: https://doi.org/10.37745/ijbmr.2013 
Vol.10, No.1, pp.1-12, 2022

Print ISSN: 2052-6393(Print),

Online ISSN: 2052-6407(Online)

\section{Recommendation}

Based on the findings of the study, it is recommended that top management of organizations should exhibit high level of commitment through leadership, support, adequate allocation of resources to the organizations, while getting more involved in salesforce activities, if the goals of the organization must be achieved.

\section{References}

Adam, X. F. (2014). An exploratory study of sales-marketing integrative devices, European Journal of Marketing, 43(7/8), 985-1007.

Ahire, Y. P., Sanley, B. B. and Matthew, W. T. (1998). The Role of Top Management Commitment in Quality Management: An Empirical Analysis of the Auto Parts Industry. International Journal of Quality Science, 3 (1), 5-37.

Amanda, M. D. (2002), Advanced Quantitative Data Analysis, Open University Press, McGraw-Hill Education.

Arshida M. M. and Agil S. O. (2012). Critical Success Factors for Total Quality Management Implementation within the Libyan Iron and Steel Company. Tun Abdul Razak University, Graduat School of Business

Baidoun S. (2003). An Empirical Study of Critical Factors of TQM in Palestinian Organizations. Logistics Information Management, 16 (2), 156-171.

Biggar J. L. (2010). Total Quality Management in Construction. Transactions of the American Association of Cost Engineers, pp. Q.1.1-Q.1.4

Bonaventure, T. E.; Oruma, A. J.; Miranga, M. M. and Muma, R. (2014), Sales Managers: Marketing's Best Example of the Peter Principle? Business Horizons, 42, 19-26.

Bridban, J. D. (2018). The Sales-Marketing Interface in Consumer Packaged-Goods Companies: A Conceptual Framework. The Journal of Personal Selling and Sales Management, 20(2), 109-119.

Caborne, S. C. (2018), Marketing and Sales: Integrate and Prosper. www.forbes.com.

Chatterjez, A. L. (2006), Customer-initiated influence tactics in sales and marketing activities, Journal of Business \& Industrial Management, 21(6): 361-375.

Crosby, Philip B. (2019). Quality is Still Free. New York: McGraw-Hill Companies. pp. 1415.

Dangara, U.Y. (2016). Educational Resources: An Integral Component for Effective School Administration in Nigeria. Research on Humanities and Social Sciences, 6(13): 27-37.

Denise, G. G. and Emefiele, R. B. (2017), Measuring organizational performance in the absence of objective measures: The case of the privately-held firm and conglomerate business unit, Strategic Management Journal, 5(3): 265-273.

Durkins, F. P. (1999), Bridging the Gap Between Marketing and Sales, Sales and Marketing Management, 144(3): 28-31.

Evans, W. G. and Dean M. M. (2003), Designing the marketing-sales interface in B2B firms, European Journal of Marketing, 41(3/4): 257-273.

Feigenbaum, A. V. (1989). How to Implement Total Quality Control. Executive Excellence, Nov. 1989, 6 (11):15-16.

Frederick, R. V. (2016), A social psychological model of relations between marketing and sales, European Journal of Marketing, 36(7), 874-894.

ECRTD-UK https://www.eajournals.org/

ULR: https://doi.org/10.37745/ijbmr.2013 
Vol.10, No.1, pp.1-12, 2022

Print ISSN: 2052-6393(Print),

Online ISSN: 2052-6407(Online)

Goetsch, G. T.; David L. B.; and Fally, H. B. (2019). Introduction to Total Quality - Quality Management for Production, Processing and Services, 2nd edition. New Jersey: Prentice-Hall, Inc. pp. 609-648.

Gupta, S. and Mirjana, V. (2000). The contextual and Dialectal Nature of Experience, in J. A. Fitzsimmons, (eds), New Service Development, Sage Publication, Thousand Oaks, CA.

Hadesty, F. M. (2006), Entrepreneurial Orientation and Business Performance - A Replication Study, Schmalenbach Business Review, 6(2): 175-198.

Hamilton, S. P. (2017), The sales function in the twenty-first century: where are we and where do we go from here?, European Journal of Marketing, 43(8): 873-889.

Harris, F.; Maddison, B. U. and McCaffer, R. (2001). Modern Construction Management, 5th edition. Oxford: Blackwell Science Ltd. pp. 6-26.

Jackson, R. and Marshall, H. O. (2007), Strategies: Sales or marketing? You need both. www.usatoday.com

Juran, J. M. (1988). Juran on Planning for Quality. New York: The Free Press. pp. 244-271.

Kanji, Y. W. (2002), Beyond teamwork: How the wise can synchronize, Marketing Management, 5(1): 213 - 224.

Mackenzie, A. R. (2019), Bridging the divide: process, technology, and the marketing/sales interface, www.aberdeen.com.

McCathy, M. H.; Pandi, R. and Lande, F. E. (1994), Organizational Culture and Marketing: Defining The Research, Journal of Marketing, 53(1): 3-15.

Mogharch, P. L. and Ghazaleh, L. and Haghighi, B. H. (2009), Marketing Performance Measures: History and Interrelationships, Journal of Marketing Management, 15(2): 711-732.

Noe, M.; Bulliard, S. G. and Tyrone, W.U. (2000), Cultural frames that drive sales and marketing apart: an exploratory study, Journal of Business and Industrial Marketing, 21(6): 386-394.

Omware Q. (2012). Determinants of Quality Management Practices. University of Nairobi, Kenya.

Parameshwar S., Srikantia P. and Case S. S. (2000). Factors affecting implementation of TQM in Knowledge Work Enviroments: An Intergrated Framework. Weatherhead School of Management

Robbins, S. P. (2007). Management. Prentice Hall, London, UK.

Rusbult, C. E. (1983). A longitudinal test of the investment model: The development (and deterioration) of satisfaction and commitment in heterosexual involvements. Journal of Personality and Social Psychology, 45, 101-117.

Rybacka, B. B. (2018), Concurrent Marketing: Integrating Product, Sales and Service, Boston: Harvard Business School Press.

Samir, A. (2003), Business research methods, Oxford University Press.

Simpson, P. L. and Ederson, H. L. (2005), Antecedents of conflict in marketing's crossfunctional relationship with sales, European Journal of Marketing, 39(2), 1327-1344.

Snyder, R. P. (1994), Marketing as Exchange, Journal of Marketing, 39(4), 32-39.

Stein, V. U. (2006). Conceptual Issues of Linkage in the Assessment of Organizational Performance, Academy of Management Review, 7(1), 49-58.

Stevens, D. H. and Stevens, G. (2015), Marketing and the Bottom Line - the Marketing Metrics to Pump up Cash Flow, 2nd edition. Financial Times / Prentice Hall, London, UK.

ECRTD-UK https://www.eajournals.org/

ULR: https://doi.org/10.37745/ijbmr.2013 
International Journal of Business and Management Review

Vol.10, No.1, pp.1-12, 2022

Print ISSN: 2052-6393(Print),

Online ISSN: 2052-6407(Online)

Taylor, W. A.; Fred, M. and Wright, G. H. (2003). The Impact of Senior Managers' Commitment on The Success of TQM Programmes - An Empirical Study. International Journal of Manpower, 24 (5), 535-550.

Teger, T. and Tropper, N. B. (2013), A Communication-Based Marketing Model for Managing Relationships, Journal of Marketing, 6(2), 1-13.

Timo, F. V. (2018). Co-ordinating sales and marketing in consumer goods firms, Journal of Consumer Marketing, 10(2), 37-55.

Vinchur, R. S. and Denise, T. G. (2019), Marketing in the Network Economy, Journal of Marketing, 63(4), 146-163.

Wheelan, V. B. and Hunger, P. O. (2006), Measures of Marketing Success, Journal of Marketing Management, 13(4), 665-678.

Yoshida, S. W. (2007), "When Executives Speak, We Should Listen and Act Differently" in "Marketing Renaissance: Opportunities and Imperatives for Improving Marketing Thought, Practice, and Infrastructure," Journal of Marketing, 69(4), 11-26.

Zakuan, W. G.; Luna, M. and David, A. (2012), Marketing-sales interface configuration in B2B firms, Industrial Marketing Management, 39(2), 183-194. 